\title{
TGF-Beta Responsive Gene Signature
}

National Cancer Institute

\section{Source}

National Cancer Institute. T GF-Beta Responsive Gene Signature. NCI Thesaurus. Code C129769.

A data set that determines the expression of genes that are modulated by transforming growth factor beta-dependent signaling pathways. 